\title{
PENINGKATAN KEMAMPUAN PEMAHAMAN KONSEP MATEMATIKA SISWA MELALUI MODEL PEMBELAJARAN PROBING PROMPTING
}

\author{
Astri Siti Sadiah ${ }^{1}$, Elsa Komala ${ }^{2}$, Rani Sugiarni $^{3}$ \\ 1, 2,3 Jurusan Pendidikan Matematika, Universitas Suryakancana, Cianjur \\ 1 astri.sitisadiah02@gmail.com \\ 2elsakomala@gmail.com \\ ${ }^{3}$ ranisugiarni@gmail.com
}

\begin{abstract}
Abstrak: Penelitian ini bertujuan untuk menjawab apakah setelah penerapan model pembelajaran Probing Prompting dapat meningkatkan kemampuan pemahaman konsep matematika siswa di kelas VII SMP Al-Azhary Cianjur. Metode yang digunakan adalah metode kuasi eksperimen dengan bentuk desain The Nonequivalent Pretest-Posttest Control Group Design. Populasi penelitian ini adalah siswa kelas VII SMP Al-Azhary. Melibatkan sampel sebanyak 41 siswa yang berasal dari dua kelas dipilih melalui teknik purposive sampling. Kelas VII-A sebagai kelas eksperimen dan kelas VII-B sebagai kelas kontrol. Instrumen yang digunakan adalah instrumen tes berupa pretest dan posttest untuk mengukur kemampuan pemahaman konsep matematika dan non tes berupa angket skala sikap. Analisis data kuantitatif dalam penelitian ini menggunakan SPSS 20. Hasil analisis penelitian menunjukkan bahwa Pencapaian dan Peningkatan kemampuan pemahaman konsep matematika yang menggunakan model pembelajaran probing-prompting lebih baik daripada peningkatan kemampuan pemahaman konsep matematika yang menggunakan model pembelajaran biasa. Dengan kategori peningkatan tinggi, sikap siswa terhadap pembelajaran matematika dengan menggunakan model pembelajaran Probing Prompting sebagian besar positif.

Kata kunci: Model Pembelajaran Probing Prompting; Kemampuan Pemahaman Konsep Matematika.
\end{abstract}

\begin{abstract}
This study aims to answer whether after the applying the Probing Prompting Learning model can increase the ability to understand mathematical concepts of students in class VII of SMP Al-Azhary CianjurThe method used is Quasi Experiment with the design form The Nonequivalent Prettest-Posttest Control Group Design. The population in this study were students of class VII SMP Al-Azhary, involving a sample 41 srudents from two classes selected through purposive sampling technique. Class VII-A as the experimental class and class VII-B as the control class. The instrument used was the test instrument in the form of a pretest an posttest to measure the ability to share mathematical concepts and non-tests in the form of an attitude scale questionnaire. Quantitative data analysis in this study used SPSS 20. The result of the research analysis showed that the achievement and improvement of the ability to understand mathematical concepts using Probing Prompting learning models was better than achieving and increasing the ability to understand mathematical concepts using ordinary learning models with high increase categories. The attitude toward mathematics learning using the Probing Prompting learning model is mostly positive.
\end{abstract}

Keywords: Probing Prompting Learning Model; Understanding Ability Mathematics Concepts.

\section{Pendahuluan}

Pada hakikatnya proses pembelajaran digunakan sebagai sarana atau sumbangan untuk mencapai tujuan pembelajaran serta dapat mengembangkan dan meningkatkan aktivitas belajar yang dilakukan guru dan siswa. Matematika adalah salah satu ilmu yang sangat penting dalam hidup, ilmu ini demikian penting, maka konsep dasar matematika yang diajarkan kepada seorang anak, haruslah benar dan kuat. 
Hitungan dasar yang melibatkan penjumlahan, pengurangan, perkalian, dan pembagian harus dikuasai dengan sempurna. Setiap orang, siapapun dia, pasti bersentuhan dengan salah satu konsep di atas dalam kesehariannya (Setyono, 2005:1). Langkah-langkah pembentukan konsep dasar matematika dalam otak dan memori anak haruslah memperhatikan aspek-aspek fisiologis dan fungsional otak, kematangan emosional, gaya belajar, kepribadian, dan tahap-tahap perkembangan anak itu sendiri (Setyono, 2005:15). Pada pembelajaran matematika harus terdapat keterkaitan antara pengalaman belajar siswa sebelumnya dengan konsep yang akan diajarkan. Dalam matematika setiap konsep berkaitan dengan konsep lain, dan suatu konsep menjadi pra syarat bagi konsep yang lain. Oleh karena itu, siswa harus lebih banyak diberi kesempatan untuk melakukan keterkaitan tersebut (Heruman, 2007:4)

Menurut Annajmi (2016: 2), pemahaman konsep merupakan suatu kemampuan yang perlu diperhatikan, namun kenyataan yang ditemukan, kemampuan pemahaman konsep yang dimiliki siswa saat ini masih belum menunjukkan adanya kemampuan pemahaman konsep yang baik, rendahnya kemampuan pemahaman konsep siswa terhadap matematika terlihat dari cara siswa dalam menyelesaikan soal-soal yang diberikan, siswa kesulitan menyelesaikan soal-soal yang berbeda dari contoh-contoh yang diberikan guru, siswa hanya berfokus pada contoh-contoh yang telah diberikan guru. Siswa masih belum dapat mengungkapkan kembali dengan lengkap konsep yang telah dipelajari, begitu juga menggunakan konsep dalam pemecahan masalah, masih banyak ditemukan siswa kesulitan dalam menjawab soal-soal yang diberikan guru, dikarenakan siswa tidak paham menggunakan konsep yang mana untuk pemecahan masalah tersebut. Salah satu cara atau alternatif agar siswa dapat memahami konsep matematika yaitu dengan cara pembelajaran yang bermakna salah satunya pemahaman secara konseptual dan pemahaman secara prosedural. Pemahaman konseptual mengacu pada pemahaman konsep dan kemampuan memecahkan masalah, sedangkan pemahaman prosedural mengacu pada keterampilan melakukan pengerjaan prosedural.

Menurut Shadiq (2009:9) bahwa model pembelajaran seperti guru secara langsung memberikan materi, konsepkonsep dan contoh-contoh pada saat pembelajaran, dapat dikatakan lebih menekankan siswa untuk mengingat (memorizing) atau menghafal (rote learning) dan kurang atau malah tidak menekankan kepada siswa untuk bernalar (reasoning), memecahkan masalah (problem solving) ataupun pada pemahaman (understanding). Dengan demikian pembelajaran seperti itu akan membuat keaktifan siswa menjadi sangat rendah, dan tidak memberi kemungkinan bagi siswa untuk berpikir dan berpartisipasi aktif secara penuh. Salah satu pembelajaran yang disarankan supaya keaktifan siswa lebih meningkat dan pembelajaran menjadi bermakna dan memungkinkan dapat meningkatkan pemahaman konsep matematika siswa, guru harus berupaya memilih dan menerapkan model pembelajaran yang dapat mengakomodasi permasalahan tersebut. Model pembelajaran yang dimungkinkan dapat memfasilitasi masalah tersebut adalah model pembelajaran Probing Prompting. Model pembelajaran Probing Prompting guru menyajikan serangkaian pertanyaan yang sifatnya menuntun dan menggali sehingga sehingga terjadi proses berpikir yang mengaitkan pengetahuan dan pengalaman siswa dengan pengetahuan baru yang sedang dipelajari (Khitotul, 2012: 5) 
Model pembelajaran ini nantinya guru akan menunjuk salah satu siswa untuk menanyakan soal yang bersangkutan dengan materi yang sedang dipelajari, jika siswa yang ditunjuk tersebut kesulitan menjawab, maka guru membantu memberi klu jawaban tetapi jika masih tidak bisa menjawab maka guru akan melemparkan pertanyaan tersebut kepada siswa yang ditujuk lagi, sehingga mau tidak mau siswa harus memperhatikan dan berkonsentrasi setiap materi yang dibahas oleh guru, dengan begitu siswa makin lama akan semakin aktif karna terbiasa dengan model pembelajaran tersebut, tidak hanya membuat aktif model pembelajaran tersebut akan membuat pembelajaran menjadi lebih bermakna dan jika pembelajaran sudah bermakna itu artinya semua materi yang telah dipelajari dapat dipahami oleh siswa. (Nurhikmah, 2016: 12)

Berdasarkan penelitian Aprillian (2017), pembelajaran Probing Prompting dapat meningkatkan kemampuan pemahaman konsep matematika, yang hasilnya diperoleh melalui soal tes evaluasi yang dilaksanakan dalam II siklus, dengan hasil penelitian siklus I pemahaman konsep masih rendah dengan rata-rata sebesar $71,95 \%$ dengan kategori cukup. Sedangkan pada siklus II terjadi peningkatan dengan rata-rata sebesar $89,1 \%$ dengan kategori baik.

Berdasarkan uraian yang telah dikemukakan sebelumnya, penelitian ini difokuskan pada peningkatan kemampuan pemahaman konsep matematika siswa melalui model pembelajaran Probing Prompting, penelitian ini penting dilakukan untuk mengetahui apakah dengan menggunakan model pembelajaran Probing Prompting dapat meningkatakan kemampuan pemahaman konsep matematika siswa serta menjawab rumusan masalah.

\section{Metode Penelitian}

Metode penelitian yang dilakukan dalam penelitian ini adalah metode kuasi eksperimen, dengan desain kelompok The Non equivalent Pretest-Postes Control Group Design. Terdapat dua grup dalam design eksperimen ini, yaitu grup kelas eksperimen dan grup kelas kontrol. Sebelum dilakukan penelitian kedua kelompok diberikan tes awal (Pretest) untuk mengetahui keadaan awal, pada kelompok pertama sebagai kelas eksperimen dan kelompok kedua sebagai kelas kontrol. Selama penelitian berlangsung, kelompok kelas eksperimen diberikan perlakuan khusus yaitu pembelajarannya menggunakan model Probing Prompting sedangkan kelompok kelas kontrol hanya diberikan perlakuan pembelajaran biasa. Kemudian di akhir penelitian kedua kelompok diberikan tes akhir (Postes) yang sama.

Populasi dalam penelitian ini adalah siswa kelas VII sekolah SMP AlAzhary Cianjur. Adapun yang dijadikan sampel penelitian ini adalah kelas VII-A dan Kelas VII-B dipilih sebanyak 2 kelas dari dua kelas yang ada. Kelas VII-A sebagai kelas eksperimen menggunakan model pembelajaran Probing Prompting, kemudian kelas VII-B sebagai kelas kontrol menggunakan model pembelajaran biasa. Dipilih dengan menggunakan teknik purposive sampling, yaitu teknik penentuan sampel dengan pertimbangan tertentu (Sugiyono, 2013: 124). Dalam penelitian ini variabel bebasnya adalah model pembelajaran Probing Prompting dan variabel terikatnya adalah kemampuan pemahaman konsep matematika.

Pengolahan analisis data menggunakan software SPSS versi 20. Yang harus dicari yaitu data pretes untuk mengetahui kemampuan awal siswa, postes untuk mengetahui pencapaian siswa dan indeks gain untuk mengetahui apakah ada peningkatan. Untuk melihat kemampuan awal, pencapaian dan 
peningkatan yaitu dengan cara uji normalitas, uji homogenitas dan uji kesamaan dua rata-rata atau Mann Whitney.

Uji normalitas digunakan untuk mengetahui apakah data berasal dari populasi yang berdistribusi normal atau tidak berdistribusi normal. Jika setelah diuji data kelas eksperimen dan kelas kontrol keduanya berdistribusi normal maka data tersebut berdistribusi normal, tetapi jika salah satu kelas datanya tidak berdistribusi normal maka data tersebut dianggap tidak berdistribusi normal. Jika data berdistribusi normal, langkah selanjutnya adalah dengan Uji homogenitas.

Uji homogenitas dilakukan untuk mengetahui apakah data tersebut berasal dari populasi yang memiliki varians homogen atau tidak. Jika data berdistribusi normal dan homogen maka dilanjutkan dengan uji-t atau uji kesamaan dua rata-rata tetapi jika data berditribusi normal dan tidak homogen atau data tidak berditribusi normal dan tidak homogen maka dilanjutkan dengan uji-t' atau Mann Whitney

Jika Kemampuan awal dan Pencapaian dapat dilihat dari nilai pretes dan postes, maka untuk melihat peningkatan kemampuan pemecahan masalah dengan menggunakan model Probing Prompting dapat dilihat dari indeks gain dengan rumus:

Indeks gain $=\frac{\text { skor posttest }- \text { skor pretest }}{\text { skor ideal }- \text { skor pretest }}$

\section{Hasil dan Pembahasan}

Metode penelitian yang dilakukan dalam penelitian ini adalah metode kuasi eksperimen, dengan desain kelompok The Non equivalent Pretest-Postes Control Group Design. Terdapat dua grup dalam design eksperimen ini, yaitu grup kelas eksperimen dan grup kelas kontrol. Sebelum dilakukan penelitian kedua kelompok diberikan tes awal (Pretest) untuk mengetahui keadaan awal, pada kelompok pertama sebagai kelas eksperimen dan kelompok kedua sebagai kelas kontrol. Selama penelitian berlangsung, kelompok kelas eksperimen diberikan perlakuan khusus yaitu pembelajarannya menggunakan model Probing Prompting sedangkan kelompok kelas kontrol hanya diberikan perlakuan pembelajaran biasa. Kemudian di akhir penelitian kedua kelompok diberikan tes akhir (Postes) yang sama.

Populasi dalam penelitian ini adalah siswa kelas VII sekolah SMP AlAzhary Cianjur. Adapun yang dijadikan sampel penelitian ini adalah kelas VII-A dan Kelas VII-B dipilih sebanyak 2 kelas dari dua kelas yang ada. Kelas VII-A sebagai kelas eksperimen menggunakan model pembelajaran Probing Prompting, kemudian kelas VII-B sebagai kelas kontrol menggunakan model pembelajaran biasa. Dipilih dengan menggunakan teknik purposive sampling, yaitu teknik penentuan sampel dengan pertimbangan tertentu (Sugiyono, 2013: 124). Dalam penelitian ini variabel bebasnya adalah model pembelajaran Probing Prompting dan variabel terikatnya adalah kemampuan pemahaman konsep matematika.

Pengolahan analisis data menggunakan software SPSS versi 20. Yang harus dicari yaitu data pretes untuk mengetahui kemampuan awal siswa, postes untuk mengetahui pencapaian siswa dan indeks gain untuk mengetahui apakah ada peningkatan. Untuk melihat kemampuan awal, pencapaian dan peningkatan yaitu dengan cara uji normalitas, uji homogenitas dan uji kesamaan dua rata-rata atau Mann Whitney.

Uji normalitas digunakan untuk mengetahui apakah data berasal dari populasi yang berdistribusi normal atau tidak berdistribusi normal. Jika setelah diuji data kelas eksperimen dan kelas kontrol keduanya berdistribusi normal maka data tersebut berdistribusi normal, 
tetapi jika salah satu kelas datanya tidak berdistribusi normal maka data tersebut dianggap tidak berdistribusi normal. Jika data berdistribusi normal, langkah selanjutnya adalah dengan Uji homogenitas.

Uji homogenitas dilakukan untuk mengetahui apakah data tersebut berasal dari populasi yang memiliki varians homogen atau tidak. Jika data berdistribusi normal dan homogen maka dilanjutkan dengan uji-t atau uji kesamaan dua rata-rata tetapi jika data berditribusi normal dan tidak homogen atau data tidak berditribusi normal dan tidak homogen maka dilanjutkan dengan uji-t' atau Mann Whitney

Jika Kemampuan awal dan Pencapaian dapat dilihat dari nilai pretes dan postes, maka untuk melihat peningkatan kemampuan pemecahan masalah dengan menggunakan model Probing Prompting dapat dilihat dari indeks gain dengan rumus:

Indeks gain $=\frac{\text { skor pos ttest }- \text { skor pretest }}{\text { skor ideal }- \text { skor pretest }}$

\section{Kesimpulan}

Berdasarkan dari hasil dan pembahasan dari data penelitian diperoleh kesimpulan bahwa baik pencapaian ataupun peningkatan kemampuan pemahaman konsep matematika siswa dengan menggunakan model pembelajaran Probing Prompting keduanya lebih baik dari pada pencapaian dan peningkatan kemampuan pemahaman konsep matematika siswa dengan menggunakan model pembelajaran biasa.

$$
\text { Sikap siswa terhadap }
$$

pembelajaran matematika dengan menggunakan model Probing Prompting sebagian besar postif.

\section{Daftar Rujukan}

Annajmi. (2016). Peningkatan kemampuan pemahaman konsep matematik siswa SMP melalui metode penemuan terbimbing berbantuan software geogebra. $M E S$ Journal of Mathematics Education and Science, 2,2528-4363.

Aprilian, E. (2017). Peningkatan pemahaman konsep dan komunikasi matematika dengan metode pembelajaran probing prompting pada siswa kelas VIII A SMP Negeri

Purworejo. EKUIVALEN-

Pendidikan Matematika, 27(2).

Heruman. (2007). Model Pembelajaran Matematika. Bandung: PT Remaja Rosdakarya

Khitotul, Fitroh. (2012). Pengaruh model pembelajaran teknik probing prompting terhadap pemahaman konsep dan keterampilan siswa kelas VIII MTs Negeri Langkapan Srengat Blitar. Retrieved fromhttp://repo.iaintulungagung.ac.id/789/.

Nurhikmah, Meydha. (2016). Penerapan model pembelajaran probing prompting untuk meningkatkan kemampuan pemahaman dan disposisi matematika siswa SMK. Retrieved fromhttp://repository.unpas.ac.id/10 132/.

Setyono, B. (2005). Penyusun bahan ajar $p d f$. Retrieved fromhttp://www.ubb.ac.id.

Shadiq, Fadjar. (2009). Model-model pembelajaran matematika SMP. Jakarta: Nurul Hidayah. Depdiknas

Sugiyono. (2013). Metode penelitian kuantitatif, kualitatif, dan kombinasi (Mixed Methods). Bandung: CV. Alfabeta.

Upita, Moni. (2018). Penerapan teknik probing prompting untuk meningkatan kemampuan pemahaman konsep matematika siswa. Retrieved fromhttp://repository.ar-raniry.ac.id. 